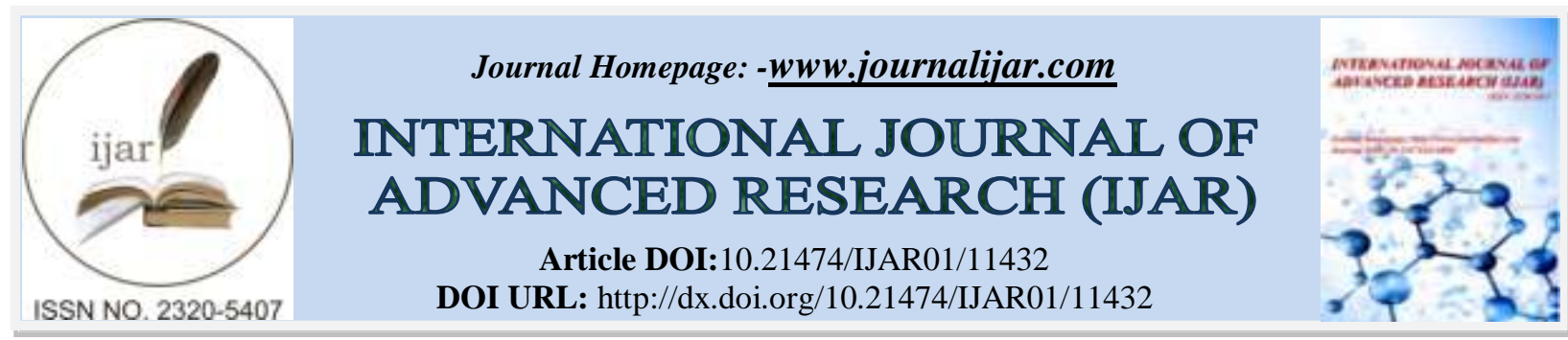

SHORT COMMUINCATION

\title{
RANDOMIZED CONTROL TRAIL: EFFECT OF OXYGEN COMPRESSED COLD APPLICATION ON PAIN AMONG PATIENTS WITH MUSCULOSKELETAL DISORDERS AT PUDUCHERRY
}

\author{
Ms. Malarmathi M. and Dr. Renuka K
}

\section{Manuscript Info}

Manuscript History

Received: 28 May 2020

Final Accepted: 30 June 2020

Published: July 2020

Key words:-

Musculoskeletal Disorders, Oxygen

Compressed Cold Application,

Conventional Cold Application

\section{Abstract}

Musculoskeletal Disorders are a persistent and a pervasive health problem which impose an enormous burden on the society. Conventional cold application using ice cap serves as one of the major treatment modality in reducing pain among these patients. Conventional cold application also have certain demerits as well. So, the Oxygen compressed cold application which is designed and invented by the investigator. Since,itis theoxygen compressed cold application, to check the usability/utility as effect ofConventional cold application, this study was used to compare the effectiveness ofconventional cold application vs oxygen compressed cold. Result of this study will help to decide whichever method is useful and to implement user-friendly in thehospital.

Aims: To assess the level of pain among patients with musculoskeletal disordersduring pre-test and post -test. To evaluate the effectiveness of oxygen compressed cold application on pain among patients with musculoskeletal disorders. To associate the level of pain among patients with musculoskeletal disorders with selected demographic variables.

Methods:Quantitative research approach was adopted in this study. A total subjects who fulfilled the inclusion criteria were selected for the study using Randomized control trail (RCT). The study setting were selected by purposive sampling technique. Demographic variables were collected using interview schedule. Pain outcome of the patients withmusculoskeletal disorders was assessed using Numeric pain intensity scale. Pre test was done through numeric pain intensity scale. Conventional cold application using ice cap was given, Oxygen compressed cold application was given.Post test was done through numeric pain intensity scaleusing after a period of 30minutes.

Results: The result shows thatmusculoskeletal painto assess the effectiveness of Oxygen compressed cold application on pain among patients with musculoskeletal disorders.

Conclusion: The main aim of the study to assess the effectiveness of Oxygen compressed cold application on pain among patients with musculoskeletal disorders. Thus, it was concluded Oxygen compressed cold application effective on pain among patients with musculoskeletal disorders. 


\section{Introduction:-}

Musculoskeletal conditions are prevalent and their impact is pervasive They are the most common cause of severe long term pain and physical disability, and they affect hundreds of millions of people around the world. They significantly affect the psychosocial status of affected people as well as their families and carers.. ${ }^{1}$

They are diverse in terms of pathophysiology but are anatomically linked, and their association with pain and impaired physical function encompasses a spectrum of conditions, ranging from acute onset and short-lived to lifelong conditions such as osteoarthritis, rheumatoid arthritis, osteoporosis, and low back pain. Prevalence of many of these conditions increases with age, and many are affected by lifestyle factors, such as obesity and lack of physical activity etc. Increase number of older people and the changes in lifestyle throughout the world mean that the burden on people and society will increase dramatically. ${ }^{2}$

Musculoskeletal conditions are common in men and women of all ages across all socio demographic strata of society. They are the most common cause of severe long-term pain and physical disability and affect hundreds of millions of people around the world. ${ }^{3}$

According to the ICD 11, chronic musculoskeletal pain states that "persistent or recurrent pain that arises as part of a disease process directly affecting bones, joints, muscles, or related soft tissue(s). ${ }^{4}$

The most common chronic condition in both developed and developing countries is musculoskeletal disability, as approximately $25 \%$ of adult subjects suffer from persistent musculoskeletal pain. ${ }^{5}$

Musculoskeletal conditions affect nearly more than 1.7 billion people worldwide and have the fourth greatest impact on the overall health of the world population, considering both death and disability. This burden has increased by $45 \%$ during the past 20 years and will continue to escalate unless action is taken.. ${ }^{6}$

Musculoskeletal conditions impairments will increase over the next 25 years, as they are most prevalent in older segments of the population. By 2040, 1 in 5 persons in the US will be age 65 or older and approximately equal to the cohort age 18 and younger. ${ }^{7}$

So has to reduce pain, cold treatments are delivered by means of packs, baths, vapocoolant sprays, or ice massage. Use of bags of crushed ice or cold gel packs secured to various anatomical sites with bandaging or elastic wraps is a common observation in used everywhere. ${ }^{8}$

In this setting, cryotherapy means ice application with some degree of concomitant static compression is routinely applied immediately after an acute musculoskeletal injury (eg, ankle sprain, muscle pull) or as prophylaxis for chronic orthopedic sports problems (eg, tennis elbow). Indeed, the long held dictum among physical therapists in the management of soft tissue trauma remains protection, rest, ice, compression and elevation.. ${ }^{9,10}$

The physiological effects of cold are generally the opposite of warm effects. The effects of cold are vasoconstriction, a slowdown in cell metabolism, local anesthesia, decrease in blood flow, reduction of the arrival of oxygen and metabolites to the area and the reduction of residuum removal. ${ }^{11}$

Cold application is a simple and inexpensive therapy which has been accepted for decades as an effective non pharmacological intervention for oedema and as well as pain management. It reduces the oedema in acute soft tissue injuries. Cold is commonly used in the treatment of acute soft tissue injuries to relieve pain, it reduces oedema.

Cold and compression are routinely applied immediately after acute injury or following surgery to alleviate pain, reduce swelling and speed functional recovery. ${ }^{12}$

\section{Need for the study:}

Musculoskeletal conditions were the main source of incapacity in four of the six WHO areas in 2017 (positioned second in the East Mediterranean Region and third in the African Region). While the prevalence of musculoskeletal conditions increases with old age, younger people are additionally influenced, regularly during their peak incomeearning years. ${ }^{13}$ 
WHO's Study on global ageing and adult health point to the high prevalence of arthritis in low class and middle class income people, particularly among those in a lower socio economic status people. ${ }^{14}$

Current estimates of people affected worldwide include back pain 632 million, neck pain 332 million, osteoarthritis of the knee 251 million, and other Musculoskeletal conditions 561 million. Worldwide low back pain is leading cause of disability and contributes $10.7 \%$ of all YLDs. Low back pain (83.1 million YLDs), neck pain (33.6 million YLDs), and osteoarthritis (17.1 million YLDs) are chief causes of Musculoskeletal conditions problems. ${ }^{15}$

The Global Burden of Disease (GBD) study provides evidence of the impact of musculoskeletal conditions, highlighting the significant disability burden associated with these conditions. In the 2017 GBD study, musculoskeletal conditions were the highest contributor to global disability (accounting for $16 \%$ of all years lived with disability). ${ }^{16}$

Although the incidence of musculoskeletal disorders varies by age and diagnosis, $20 \%-33 \%$ of people worldwide are suffering from a debilitating musculoskeletal disease. ${ }^{17}$

A recent report from the United States of America suggests that one in two adult Americans live with a musculoskeletal condition - the same number as those with cardiovascular or chronic respiratory diseases combined. $^{18}$

Arthritis is the most common cause of adult disability in the US, and a leading cause of job limitations. By 2030 , it is projected that the number of adults affected by doctor-diagnosed arthritis will reach 67 million, or 25 per cent of the population. Close to 50 per cent of people age 65 and older report arthritis ${ }^{19}$

In India the general community is burdened by musculoskeletal disorders. Cross-sectional study of 2086 National Capital Region (NCR) subjects; Total MS pain prevalence was estimated to be $25.9 \%$. Pain among females (31.3 percent) was found to be more prevalent compared with males (20.9 percent). Our findings confirm that MS pain is a significant burden of disease among the residents of NCR. ${ }^{20}$

The prevalence of musculoskeletal pain and joint complaints was performed at one of Puducherry Jawaharlal Institute of Postgraduate Medical Education and Research (JIPMER). Using prevalence of the musculoskeletal complaints as $26.08 \%$, and an absolute precision of 5\%, the required sample size was 296 those who are affected with musculoskeletal conditions. ${ }^{21}$

Cold compression is used internally or systemically for medical purposes and helps to decrease the temperature of the tissue. For the treatment of knee osteoarthritis, the goal is to enhance the quality of life by minimizing discomfort, stiffness and other symptoms, preventing disease development, improving and preserving the patient's physical function. In this respect, cold application is thought to help treatment, as it has low side effects, easy application and non-invasive application. ${ }^{22}$

It also directly addresses the swelling, inflammation and pain associated with these injuries, this modality has been extended to the post-operative management of a variety of orthopedic procedures. ${ }^{23}$

In a study conducted by Melzack, cold application massage and TENS therapy were compared between patients with back pain and it was stated that ice massage applied to the trigger points of muscle pain, skeletal pain, soft tissue pain and joint pain offered better relief and relaxation so that it was concluded that cold application massage was an effective therapeutic process. ${ }^{24}$

A research by Bleakley et al demonstrated regular application of cold in the early stages of recovery following ankle sprains resulted in substantially improved subjective pain management. ${ }^{25}$

The researcher felt that the Oxygen compressed cold application which is a newly designed Oxygen compressed cold application invented by the investigator can overcome the non-availability ofConventional cold application using ice cap and can be replaced with cold water with oxygen produced through electricity. 
The electrical device is designed and developed for pain reduction, to check the usability/utility and the effect of conventional cold application using ice cap. This study was chosen to compare the effectiveness of Conventional cold application VS Oxygen compressed cold application .

The result of this study will help to decide the best method to treat pain and to implement user-friendly approach in the hospital. Thus, the investigator had taken up this study with the aim of replacing Conventional cold application with Oxygen compressed cold application.

\section{Objectives:-}

1. To assess the level of pain among patients with musculoskeletal disorders during pre-test and post -test.

2. To evaluate the effectiveness of oxygen compressed cold application on pain among patients with musculoskeletal disorders.

3. To associate the level of pain among patients with musculoskeletal disorders with selected demographic variables.

\section{Hypotheses:}

H1-Association exists between levels of pain among patients with musculoskeletal disorders and selected demographic variables.

\section{Methodology:-}

Quantitative research approach was adopted in this study. A total of 90 subjects who fulfilled the inclusion criteria were selected for the study using Randomized control trail (RCT). The study setting were selected by purposive sampling technique. The study setting was Male and Female ortho wards of Puducherry. Demographic variables were collected using interview schedule. Pain outcome of the patients withmusculoskeletal disorders was assessed using numeric pain intensity scale. Oxygen compressed cold application was given.Post test was done through numeric pain intensity scaleusing after a period of 30 minutes.

\section{Criteria for SampleSelection:}

Inclusion Criteria:

1. Patient diagnosed with musculoskeletaldisorders

2. Patient with age more than 18 years

3. Patient who isconscious.

\section{Exclusion Criteria:}

1. Patient who isrestless.

2. Unresponsivepatient.

3. Systemiccomplications

\section{Part 1:}

It consists of interview schedule to assess the demographic data such as age, gender, educational status, occupation, monthly income, religion, residential area, duration of musculoskeletal pain, undergoing any pain relieving measures, duration of working hours per day and frequency of follow up.

\section{Part 2:}

It includes assessment of the pain intensity using numeric pain intensity scale.

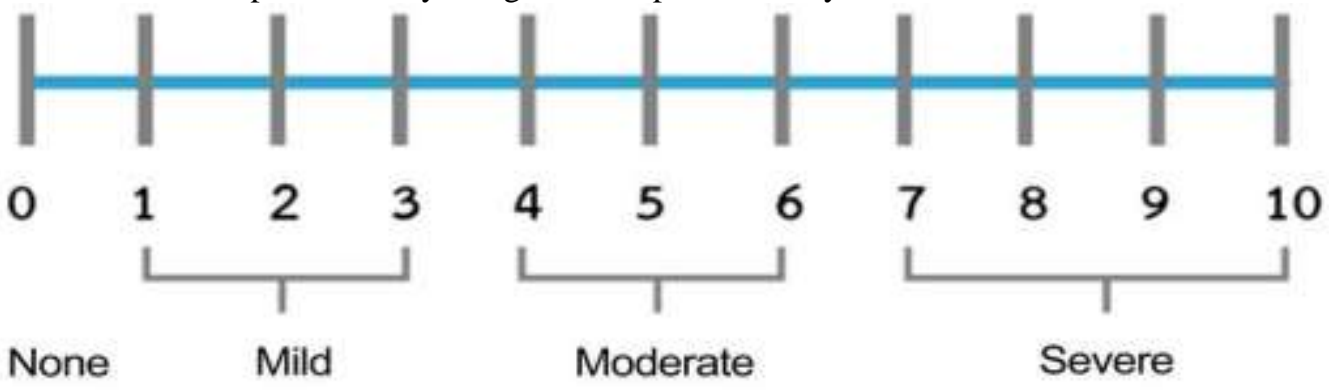


Table 1:- Frequency and percentage wise distribution of Pre-test and post- test of the level of pain (numeric pain intensity scale) amongpatients with musculoskeletal disorders in oxygen compressed cold application group.

\begin{tabular}{|l|l|}
\hline SCORE (GRADING) & PAIN INTERPRETATION \\
\hline 0 & NO PAIN \\
\hline $1-3$ & MILD PAIN \\
\hline $4-6$ & MODERATE PAIN \\
\hline $7-10$ & SEVERE PAIN \\
\hline
\end{tabular}

$(\mathbf{N}=30)$

Table 1:- Frequency and percentage wise distribution of Pre-test and post- test of the level of pain (numeric pain intensity scale) among patients with musculoskeletal disorders inoxygen compressed cold application group. In pretest, Majority of the musculoskeletal pain patients $19(63.3 \%)$ had severe level, 6(20\%) had mild level and 5 $(16.7 \%)$ had moderate level of pain. The mean and standard deviation of the level of pain (numeric pain intensity scale) among musculoskeletal pain patients in pre-test is $(6.40+2.44)$.

\begin{tabular}{|c|c|c|c|c|c|c|}
\hline \multirow{2}{*}{$\begin{array}{l}\text { OXYGEN COMPRESSED COLD } \\
\text { APPLICATION GROUP } \\
\text { LEVEL OF PAIN }\end{array}$} & \multicolumn{3}{|c|}{ PRE TEST } & \multicolumn{3}{|c|}{ POST TEST } \\
\hline & $\begin{array}{l}\text { Frequen } \\
\text { cy }(\mathrm{N})\end{array}$ & $\begin{array}{l}\text { Percenta } \\
\text { ge }(\%)\end{array}$ & $\begin{array}{l}\text { Mean } \\
\text { Standard } \\
\text { Deviation }\end{array}$ & $\begin{array}{l}\text { Frequen } \\
\text { cy }(\mathrm{N})\end{array}$ & $\begin{array}{l}\text { Percenta } \\
\text { ge }(\%)\end{array}$ & $\begin{array}{l}\text { Mean } \\
\text { Standard } \\
\text { Deviation }\end{array}$ \\
\hline No pain & 0 & 0 & \multirow{5}{*}{$6.40+2.44$} & 0 & 0 & \multirow{5}{*}{$2.90+1.422$} \\
\hline Mild & 6 & 20 & & 23 & 76.7 & \\
\hline Moderate & 5 & 16.7 & & 7 & 23.3 & \\
\hline severe & 19 & 63.3 & & 0 & 0 & \\
\hline Total & 30 & 100 & & 30 & 100 & \\
\hline
\end{tabular}

In post-test, Majority of the musculoskeletal pain patients $23(76.7 \%)$ had mild level and $7(23.3 \%)$ had moderate level of pain. The mean and standard deviation of the level of pain (Numeric pain intensity scale) among musculoskeletal pain patients in post-test is $(2.90+1.422)$ respectively.

\section{Oxygen compressed cold application group- Pre and Post test- level of pain (NUMERICAL PAIN SCALE)}

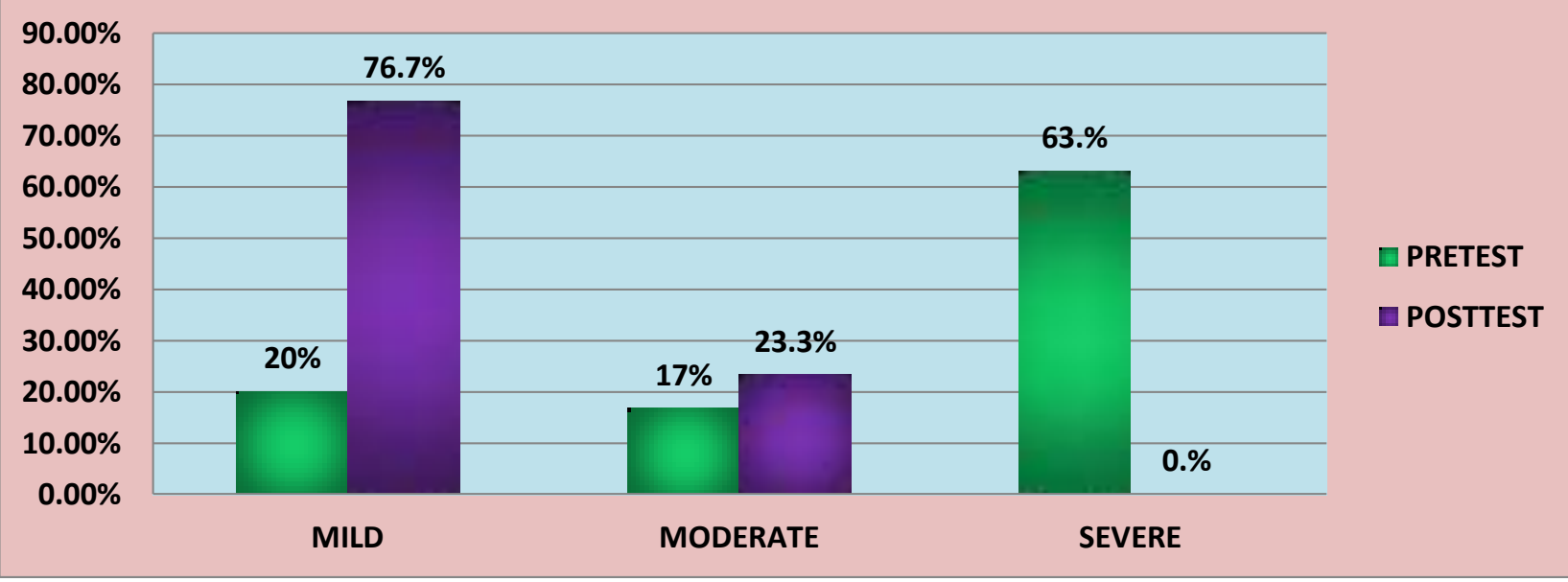

Fingure 1:- Frequency and percentage wise distribution of Pre-test and post- test of the level of pain (numeric pain intensity scale) amongpatients with musculoskeletal disorders in oxygen compressed cold application group. 
Table 2:-Pre-test and post- test of the level of pain ( Numeric pain intensity scale)amongpatients with musculoskeletal disorders inOxygen compressed cold application group. $(\mathrm{N}=30)$.

\begin{tabular}{|l|l|l|l|l|l|}
\hline GROUP & $\begin{array}{l}\text { LEVEL OF PAIN (NUMERIC } \\
\text { PAIN INTENSITY SCALE) }\end{array}$ & $\begin{array}{l}\text { ME } \\
\text { AN }\end{array}$ & $\begin{array}{l}\text { STANDARD } \\
\text { DEVIATON }\end{array}$ & $\begin{array}{l}\text { 't' } \\
\text { VAL } \\
\text { UE }\end{array}$ & $\begin{array}{l}\text { 'p' } \\
\text { VALU } \\
\text { E }\end{array}$ \\
\hline $\begin{array}{l}\text { OXYGEN COMPRESSED } \\
\text { COLD APPLICATION }\end{array}$ & Pre-test & 6.40 & 2.443 & 6.459 & $.001 * *$ \\
\cline { 2 - 6 } & Post-test & 2.90 & 1.422 & \\
\hline
\end{tabular}

**-p $<0.001$ highly significant

Table shows that, the mean score of in thelevel of pain pre-test was $6.40 \pm 2.443$ and the mean score in the posttest was $2.90 \pm 1.422$ respectively.

The calculated paired ' $t$ ' test value of $t=6.459$ shows statistically highly significant betweenComparison of thePretest and post- test of the level of pain ( numeric pain intensity scale) among patients with musculoskeletal disorders in oxygen compressed cold application group respectively.

Table 3:- Association between the Post-test of the level of pain (numeric pain intensity scale)among patients with musculoskeletal disorderswith their selected demographic variables in oxygen compressed cold application group.

$(\mathrm{N}=30)$.

\begin{tabular}{|c|c|c|c|c|c|}
\hline \multirow{5}{*}{$\begin{array}{l}\text { DEMOGRAPHIC } \\
\text { VARIABLES }\end{array}$} & \multirow{3}{*}{\multicolumn{4}{|c|}{$\begin{array}{l}\text { OXYGEN COMPRESSED COLD APPLICATION } \\
\text { POST-TEST OF LEVEL OF PAIN } \\
\text { NUMERIC PAIN INTENSITY SCALE }\end{array}$}} & \multirow[t]{5}{*}{ p-VALUE } \\
\hline & & & & & \\
\hline & & & & & \\
\hline & \multicolumn{2}{|c|}{ MILD } & \multicolumn{2}{|c|}{ MODERATE } & \\
\hline & $\mathbf{N}$ & $\%$ & $\mathbf{N}$ & $\%$ & \\
\hline \multicolumn{5}{|l|}{ Age in years } & \multirow{5}{*}{$0.032 *$} \\
\hline $18-30$ & 2 & 66.7 & 1 & 33.3 & \\
\hline $31-40$ & 9 & 90 & 1 & 10 & \\
\hline $41-50$ & 4 & 44.4 & 5 & 55.6 & \\
\hline Above 51 & 8 & 100 & 0 & 0 & \\
\hline \multicolumn{5}{|l|}{ Gender } & \multirow{3}{*}{0.400} \\
\hline Male & 9 & 69.2 & 4 & 30.8 & \\
\hline Female & 14 & 82.4 & 3 & 17.6 & \\
\hline \multicolumn{5}{|l|}{ Religion } & \multirow{4}{*}{0.319} \\
\hline Hindu & 17 & 70.8 & 7 & 29.2 & \\
\hline Christian & 3 & 100 & 0 & 0 & \\
\hline Muslim & 3 & 100 & 0 & 0 & \\
\hline \multicolumn{5}{|c|}{ Highest level of educational status } & \multirow{6}{*}{0.889} \\
\hline illiterate & 0 & 0 & 0 & 0 & \\
\hline Primary school level & 0 & 0 & 0 & 0 & \\
\hline Secondary school level & 2 & 66.7 & 1 & 33.3 & \\
\hline Higher secondary school & 6 & 75 & 2 & 25 & \\
\hline collegiate & 15 & 78.9 & 4 & 21.1 & \\
\hline \multicolumn{5}{|l|}{ Occupation status } & \multirow{6}{*}{0.372} \\
\hline Unemployed & 1 & 50 & 1 & 50 & \\
\hline Self employed & 2 & 66.7 & 1 & 33.3 & \\
\hline Farmer/coolie & 1 & 100 & 0 & 0 & \\
\hline Clerical/technical & 11 & 68.8 & 5 & 31.2 & \\
\hline Professional & 8 & 100 & 0 & 0 & \\
\hline \multicolumn{5}{|l|}{ Nature of work } & \multirow{4}{*}{0.701} \\
\hline Sedentary worker & 2 & 100 & 0 & 0 & \\
\hline Moderate worker & 14 & 73.7 & 5 & 26.3 & \\
\hline Heavy worker & 7 & 77.8 & 2 & 22.2 & \\
\hline
\end{tabular}




\begin{tabular}{|c|c|c|c|c|c|}
\hline \multicolumn{5}{|l|}{ Unhealthy habits } & \multirow{5}{*}{0.485} \\
\hline Smoking/tobacco smoking & 12 & 85.7 & 2 & 14.3 & \\
\hline Alcoholism & 4 & 57.1 & 3 & 42.9 & \\
\hline Drug abuse & 6 & 75 & 2 & 25 & \\
\hline None & 1 & 100 & 0 & 0 & \\
\hline \multicolumn{5}{|l|}{ Systemic illness } & \multirow{8}{*}{0.157} \\
\hline Diabetic mellitus & 6 & 85.7 & 1 & 14.3 & \\
\hline Hypertension & 8 & 100 & 0 & 0 & \\
\hline Thyroid disorders & 0 & 0 & 0 & 0 & \\
\hline Cardiac disorders & 1 & 50 & 1 & 50 & \\
\hline CNS disorders & 0 & 0 & 0 & 0 & \\
\hline None & 8 & 64.5 & 5 & 38.5 & \\
\hline Any other & 0 & 0 & 0 & 0 & \\
\hline \multicolumn{5}{|c|}{ Duration of treatment taking for systemic illness } & \multirow{5}{*}{0.218} \\
\hline$<1$ year & 6 & 55.6 & 4 & 44.4 & \\
\hline $1-3$ years & 3 & 75 & 1 & 25 & \\
\hline 4-6 years & 8 & 80 & 2 & 20 & \\
\hline$>6$ years & 7 & 100 & 0 & 0 & \\
\hline \multicolumn{5}{|l|}{ Duration of musculoskeletal pain } & \multirow{5}{*}{0.850} \\
\hline$<1$ year & 8 & 80 & 2 & 20 & \\
\hline $1-3$ years & 2 & 66.7 & 1 & 33.3 & \\
\hline 4-6 years & 7 & 70 & 3 & 30 & \\
\hline$>6$ years & 6 & 85.7 & 1 & 14.3 & \\
\hline \multicolumn{5}{|l|}{ Any other pain relieving measures } & \multirow{6}{*}{0.163} \\
\hline Alternative therapies & 4 & 57.1 & 3 & 42.9 & \\
\hline Use of splints & 0 & 0 & 0 & 0 & \\
\hline Use of traction & 0 & 0 & 0 & 0 & \\
\hline Others & 19 & 82.6 & 4 & 17.4 & \\
\hline None & 0 & 0 & 0 & 0 & \\
\hline \multicolumn{5}{|l|}{ Duration of working hours } & \multirow{5}{*}{0.698} \\
\hline 6 hours & 0 & 0 & 0 & 0 & \\
\hline 8 hours & 15 & 78.9 & 4 & 21.1 & \\
\hline 10 hours & 8 & 72.7 & 3 & 27.3 & \\
\hline 12 hours & 0 & 0 & 0 & 0 & \\
\hline \multicolumn{5}{|l|}{ Aggravating factors } & \multirow{5}{*}{0.167} \\
\hline Long standing & 7 & 63.6 & 4 & 36.4 & \\
\hline Fixed body position & 8 & 72.7 & 3 & 27.3 & \\
\hline Wrong practice of exercise & 8 & 100 & 0 & 0 & \\
\hline Continual repetition of movements & 0 & 0 & 0 & 0 & \\
\hline \multicolumn{5}{|l|}{ Frequency of follow up } & \multirow{4}{*}{$0.053 *$} \\
\hline Weekly once & 0 & 0 & 0 & 0 & \\
\hline Monthly once & 7 & 58.3 & 5 & 41.7 & \\
\hline Twice a year & 16 & 88.9 & 2 & 11.1 & \\
\hline \multicolumn{5}{|c|}{ Any previous history of musculoskeletal disorders } & \multirow{3}{*}{0.542} \\
\hline Yes & 7 & 70 & 3 & 30 & \\
\hline No & 16 & 80 & 4 & 20 & \\
\hline
\end{tabular}

*-p $<0.05$ significant

The table 3 depicts by using chi-square it was evidenced that the demographic variables age andFrequency of follow up is statistically significant and other varaibles had not shown statistically significant association with thePost-test of the level of pain (numeric pain intensity scale)among patients with musculoskeletal disorderswith their selected demographic variables in Oxygencompressed cold applicationgroup respectively. 


\section{Implications Of The Study:}

The investigator has derived the following implications from the study which are of primaryconcern in the field of nursing practice, nursing education, nursing administration and nursing research.

\section{Limitations:}

1. Study period was limited to 4 weeks.

2. Sample size was limited to 30 samples in eachgroup.

3. Study population was limited to patients with musculoskeletalpain

\section{Recommendations:-}

1. The study can be replicated with a larger sample for bettergeneralisation.

2. A similar study can be conducted for only the geriatricpatients.

3. A similar study can be conducted with the use of limb physiotherapy along with theapplication of oxygen compressed cold application as twintechnique.

\section{Discussion:-}

In the study in which musculoskeletal disorders patients were treated with oxygen compressed cold application, it was identified that difference between the experimental oxygen compressed cold application pre test was done by numerical rating scale according pain score level patient are categorized by mild, moderate, and severe. Intervention given pain level was reduced to severe to moderate to mild both group I, group II.

The pain intensity of patients with musculoskeletal disorders differs before and after administration of oxygen compressed cold application in all three groups. Hence the stated Hypothesis (H1) and (H2) were accepted., in post test which is significant at $\mathrm{p}<0.001$, which implies that oxygen compressed cold application was effective cold compression among musculoskeletal disorders cases concurred with the current study in terms of improvement in pain score level.

By using chi-square it was evidenced that the demographic variables age and frequency of follow up is statistically significant and other variables had not shown statistically significant association with the Post-test of the level of pain (numeric pain intensity scale) among patients with musculoskeletal disorders with their selected demographic variables in oxygen compressed cold application group respectively. There is an association between demographic variables.

\section{Conclusion:-}

The main aim of the study to assess the effectiveness of Oxygen compressed cold application on pain among patients with musculoskeletal disorders. Thus, it was concluded oxygen compressed cold applicationeffective on pain among patients with musculoskeletal disorders.

\section{References:-}

1. Woolf AD, Åkesson K. Understanding the burden of musculoskeletal conditions.

2. Malanga GA, Yan N, Stark J. Mechanisms and efficacy of heat and cold therapies for musculoskeletal injury. Postgraduate Medicine. 2015 Jan 2;127(1):57-65.

3. Woolf AD, Erwin J, March L. The need to address the burden of musculoskeletal conditions. Best practice \& research Clinical rheumatology. 2012 Apr 1;26(2):183-224.

4. Treede RD, Rief W, Barke A, Aziz Q, Bennett MI, Benoliel R, Cohen M, Evers S, Finnerup NB, First MB, Giamberardino MA. A classification of chronic pain for ICD-11. Pain. 2015 Jun;156(6):1003.

5. Woolf AD, Åkesson K. Understanding the burden of musculoskeletal conditions.

6. Murray C, Vos T, Naghavi M. Global burden of diseases, injuries and risk factors study 2013. The Lancet. $2014 \mathrm{Jul} ; 22$.

7. Ortman JM, Velkoff VA, Hogan H. An aging nation: the older population in the United States. Suitland, MD, USA: United States Census Bureau, Economics and Statistics Administration, US Department of Commerce; 2014 May 9.

8. Meeusen R, Lievens P. The use of cryotherapy in sports injuries. Sports medicine. 1986 Nov 1;3(6):398-414.

9. Kullenberg B, Ylipää S, Söderlund K, Resch S. Postoperative cryotherapy after total knee arthroplasty: a prospective study of 86 patients. The Journal of arthroplasty. 2006 Dec 1;21(8):1175-9. 
10. Raynor MC, Pietrobon R, Guller U, Higgins LD. Cryotherapy After ACL Reconstruction-A Meta-analysis. The journal of knee surgery. 2005;18(02):123-9.

11. Nurcan Ç, Karadag M. Superficial Heat and Cold Applications in the Treatment of Knee Osteoarthritis. Osteoarthritis-Progress in Basic Research and Treatment. In Tech. 2015 Jul 1:249-64.

12. Collins NC. Is ice right? Does cryotherapy improve outcome for acute soft tissue injury? Emergency Medicine Journal. 2008 Feb 1;25(2):65-8.

13. James SL, Abate D, Abate KH, et al. Global, regional, and national incidence, prevalence, and years lived with disability for 354 diseases and injuries for 195 countries and territories, 1990-2017: a systematic analysis for the Global Burden of Disease Study 2017. Lancet 2018; 392: 1789-858.

14. Brennan-Olsen SL, Cook S, Leech MT, Bowe SJ, Kowal P, Naidoo N, Ackerman IN, Page RS, Hosking SM, Pasco JA, Mohebbi M. Prevalence of arthritis according to age, sex and socioeconomic status in six low and middle income countries: analysis of data from the World Health Organization study on global AGEing and adult health (SAGE) Wave 1. BMC musculoskeletal disorders. 2017 Dec 1;18(1):271.

15. Mishra M, Srivastava AK, Srivastava VK. Prevalence and risk of musculoskeletal pain in rural homemakers of North India. Medical Journal of Dr. DY Patil University. 2017 Mar 1;10(2):138.

16. Vos T, Abajobir AA, Abate KH, Abbafati C, Abbas KM, Abd-Allah F, Abdulkader RS, Abdulle AM, Abebo TA, Abera SF, Aboyans V. Global, regional, and national incidence, prevalence, and years lived with disability for 328 diseases and injuries for 195 countries, 1990-2016: a systematic analysis for the Global Burden of Disease Study 2016. The Lancet. 2017 Sep 16;390(10100):1211-59.

17. Woolf AD, Pfleger B. Burden of major musculoskeletal conditions. Bulletin of the world health organization. 2003;81:646-56.

18. Lezin N, Watkins-Castillo S. The impact of musculoskeletal disorders on Americans-opportunities for action, executive summary of the burden of musculoskeletal diseases in the United States: Prevalence, societal and economic cost. Bone and Joint Initiative. 2016.

19. Yelin E, Weinstein S, King T. The burden of musculoskeletal diseases in the United States. InSeminars in arthritis and rheumatism 2016 Dec (Vol. 46, No. 3, p. 259).

20. Bihari V, Kesavachandran C, Pangtey BS, Srivastava AK, Mathur N. Musculoskeletal pain and its associated risk factors in residents of National Capital Region. Indian journal of occupational and environmental medicine. 2011 May;15(2):59.

21. Majumdar A, Kumar SG, Nair D, Sujiv A. Musculoskeletal complaints and predictors of musculoskeletal pain among adults in rural Puducherry. Indian journal of palliative care. 2015 Jan;21(1):121.

22. Nurcan Ç, Karadag M. Superficial Heat and Cold Applications in the Treatment of Knee Osteoarthritis. Osteoarthritis-Progress in Basic Research and Treatment. In Tech. 2015 Jul 1:249-64.

23. Raynor MC, Pietrobon R, Guller U, Higgins LD. Cryotherapy After ACL Reconstruction-A Meta-analysis. The journal of knee surgery. 2005;18(02):123-9.

24. Kocagil T. Comparison of Ice Massage and TENS in the Treatment of Knee Osteoarthrosis. Uludag University Faculty of Medicine. Thesis. 1990.

25. Bleakley CM, McDonough SM, MacAuley DC. Cryotherapy for acute ankle sprains: A randomized controlled study of two differ ent icing protocols. Br J Sports Med 2006;40(8):700-705. 